\title{
Preparation of 1,3-Dioxolanes from Epoxides and Carbonyl Compounds under Neutral Conditions
}

\author{
Tokuji TAKedA, Satoshi YasuHaRA, and Shoji WATANABE \\ Osaka Municipal Technical Research Institute (2-1-1, Ogimachi, Kita-ku, Osaka)
}

\begin{abstract}
Lithium halides catalyzed the reaction of epoxides with carbonyl compounds in a polar aprotic solvent to give 1,3-dioxolane derivatives. 2,4-Disubstituted-1,3-dioxolanes from unsynmetrically substituted epoxides (1-chloro-2,3-epoxypropane, 1,2-epoxypropane and 1,2-epoxybutane) and benzaldehyde were found to be mixtures of stereoisomers in which 2- and 4-substituents were in the cis- and trans-con= figurations. The cis/trans ratio of the resulting 1,3-dioxolanes was dependent on the type of catalyst. In the Lewis acid catalyzed reaction, the cis-isomer was preferentially formed, conversely the lithium halide catalyst offered the trans-isomer preferentially.
\end{abstract}

\section{Introduction}

1,3-Dioxolanes are very important compounds in organic synthesis as intermediates ${ }^{1), 2)}$ or pro= tecting compounds ${ }^{3}$ ) and for preparing easily hydrolyzable surfactants ${ }^{4}$. These compounds are usually prepared by the reaction of diols $^{5)}$ or epoxides $^{6}$ ) with carbonyl compounds using miner= al acids, $p$-toluenesulfonic acid, tin tetrachloride and boron trifluoride as catalyst. Recently, we reported that aluminum chloride catalyzed the reaction of epoxides with aldehydes or ketones ${ }^{7)}$. From the limitation of the synthetic procedures under acidic conditions, we investigated the synthetic method under neutral conditions.

There is only one paper to our knowledge describing a synthesis of 1,3-dioxolanes in neu= tral conditions ${ }^{8)}$. The method, reported by Ner= del, involves the reaction of ethylene oxide with aldehydes using a quarternary ammonium salt. A high temperature, usually $170 \sim 220^{\circ} \mathrm{C}$, is required to produce 1,3-dioxolanes and the reaction has not been studied in detail.

In this paper, we report a mild and facile synthetic procedure for preparing 1,3-dioxolanes under neutral conditions by the reaction of ep= oxides with carbonyl compounds, and the depen= dence of distribution of the stereoisomers on the type of catalyst.

\section{Experimental}

\section{Reaction of 1-chloro-2,3-epoxypropane} (ECH) with benzaldehyde

To a stirred solution of $\mathrm{LiBr}(0.6 \mathrm{~g}, 6 \mathrm{mmol})$, dried in vacuo prior to use, in hexamethylphos= phoric triamide (HMPA, $10.7 \mathrm{~g}, 60 \mathrm{mmol}$ ) was added $6.4 \mathrm{~g}(60 \mathrm{mmol})$ of benzaldehyde, followed by dropwise addition of $5.6 \mathrm{~g}(60 \mathrm{mmol})$ of $\mathrm{ECH}$. After being stirred at $120^{\circ} \mathrm{C}$ for $7.5 \mathrm{~h}, 5.6 \mathrm{~g}$ ( $60 \mathrm{mmol}$ ) of $\mathrm{ECH}$ was added to the mixture and the mixture was heated at $120^{\circ} \mathrm{C}$ for an additional $7.5 \mathrm{~h}$. The cooled solution was then diluted with brine and extracted with diethyl ether. The organic layer was dried over anhy= drous $\mathrm{Na}_{2} \mathrm{SO}_{4}$ and distilled. Unreacted benzal $=$ dehyde $(1.5 \mathrm{~g}, 24 \%)$ was recovered, and the product (1) $(6.2 \mathrm{~g}, 54 \%)$ was obtained. bp 93 . $\sim 94^{\circ} \mathrm{C} / 2 \mathrm{mmHg}$. IR (neat): 1230, 1090, 1070, 970, 760, and $700 \mathrm{~cm}^{-1}$. Anal. Calcd. for $\mathrm{C}_{10}$ $\mathrm{H}_{11} \mathrm{ClO}_{2}$ : C, 60.46; $\mathrm{H}, 5.58 ; \mathrm{Cl}, 17.85$. Found: C, 60.18; H, 5.82; Cl, 18.0. ${ }^{1} \mathrm{H}$ NMR $\left(\mathrm{CCl}_{4}, \delta\right)(1 \mathrm{a}): 3.3 \sim 3.8\left(3 \mathrm{H}, \mathrm{m}, \mathrm{ClCH}_{2} \mathrm{CH}\right)$, $4.18\left(2 \mathrm{H}, \mathrm{d}, J=4.5 \mathrm{~Hz}, \mathrm{OCH}_{2}\right), 5.82(1 \mathrm{H}$, $\left.\mathrm{s}, \mathrm{HC}<{ }_{\mathrm{O}}^{\mathrm{O}}\right), 7.3 \sim 7.6\left(5 \mathrm{H}, \mathrm{m}, \mathrm{C}_{6} \mathrm{H}_{5}\right) . \quad(1 \mathbf{b})$ : $3.4 \sim 4.5\left(5 \mathrm{H}, \mathrm{m}, \mathrm{ClCH}_{2} \mathrm{CHCH}_{2} \mathrm{O}\right), 6.02$ (1 $\left.\mathrm{H}, \mathrm{s}, \mathrm{HC}<{ }_{\mathrm{O}}^{\mathrm{O}}\right), 7.1 \sim 7.6\left(5 \mathrm{H}, \mathrm{m}, \mathrm{C}_{6} \mathrm{H}_{5}\right)$. Mass spectrum $(30 \mathrm{eV}):(1 \mathbf{a}) ;$ m/e 197 (ra 100), 106 
(47), 199 (31), $198\left(\mathrm{M}^{+}, 26\right), 79$ (26), 92 (25), 78 (21), 121 (11), 76 (10), and 200 (9). (1b); $m / e 197$ (ra 100), 106 (43), 79 (32), 199 (33), $198\left(\mathrm{M}^{+}, 28\right), 78$ (23), 121 (17), and 149 (11).

In the other runs of the reactions under various conditions, the recovery of benzaldehyde and the yield of (1) were determined by GLC using standard mixtures of benzaldehyde, (1), and in = ternal standard (methyl decanoate).

\section{Reaction of ECH with cyclohexanone}

To a stirred solution of $\mathrm{LiBr}(0.6 \mathrm{~g}, 6 \mathrm{mmol})$ in HMPA $(10.7 \mathrm{~g}, 60 \mathrm{mmol})$ was added $5.9 \mathrm{~g}$ $(60 \mathrm{mmol})$ of cyclohexanone, followed by drop= wise addition of $5.6 \mathrm{~g}(60 \mathrm{mmol})$ of ECH. After being stirred at $120^{\circ} \mathrm{C}$ for $8 \mathrm{~h}, 5.6 \mathrm{~g}(60 \mathrm{mmol})$ of $\mathrm{ECH}$ was added to the mixture and the mix= ture was heated at $120^{\circ} \mathrm{C}$ for an additional $7 \mathrm{~h}$. The reaction mixture was treated by the method described above, and $3.8 \mathrm{~g}(64 \%)$ of cyclohex= anone was recovered. The product (2) $(1.4 \mathrm{~g}$, 12\%) was obtained. bp $89 \sim 91^{\circ} \mathrm{C} / 4 \mathrm{mmHg}$.

IR (neat) : 1285, 1165, 1100, 1050, 930, 850, and $760 \mathrm{~cm}^{-1}$. Anal. Calcd. for $\mathrm{C}_{9} \mathrm{H}_{15} \mathrm{ClO}_{2}: \mathrm{C}$, 56.69; H, 7.93; Cl, 18.59. Found: C, 56.26; $\mathrm{H}, 7.74 ; \mathrm{Cl}, 18.8 .{ }^{1} \mathrm{H} \mathrm{NMR}\left(\mathrm{CCl}_{4}, \delta\right): 1.2 \sim$ $1.7\left(10 \mathrm{H}, \mathrm{m}, \mathrm{CH}_{2}\right), 3.1 \sim 4.3\left(5 \mathrm{H}, \mathrm{m}, \mathrm{ClCH}_{2}\right.$ $\mathrm{CHCH}_{2}$ ). Mass spectrum $(30 \mathrm{eV}): m / e 148$ (ra 100), 150 (33), 56 (23), 162 (11), 134 (10), $76(9)$, and $190\left(\mathrm{M}^{+}, 8\right)$.

In the other runs of the reactions, the recove ery of cyclohexanone and the yield of (2) were determined by GLC using standard mixtures of cyclohexanone, (2) and internal standard (methyl decanoate).

Reaction of 1,2-epoxypropane (PO) and 1,2-epoxybutane (BO) with benzaldehyde

To a solution of $\mathrm{LiBr}(0.5 \mathrm{~g}, 5 \mathrm{mmol})$ in HMPA $(9.0 \mathrm{~g}, 50 \mathrm{mmol})$ were added $5.3 \mathrm{~g}$ (50 $\mathrm{mmol})$ of benzaldehyde and $3.5 \mathrm{~g}(60 \mathrm{mmol})$ of PO. The mixture was heated in a sealed tube at $120^{\circ} \mathrm{C}$ for $8 \mathrm{~h}$ and treated according to the procedure described above. After removal of ethyl ether, the residue was distilled at reduced pressure and $1.1 \mathrm{~g}(21 \%)$ of benzaldehyde was recovered. The product (3) $(4.3 \mathrm{~g}, 53 \%)$ was obtained. bp $87 \sim 88.5^{\circ} \mathrm{C} / 4 \mathrm{mmHg}$.

IR (neat) : 1220, 1090, 1065, 1030, 980, 760, and $700 \mathrm{~cm}^{-1}$. Anal. Calcd. for $\mathrm{C}_{10} \mathrm{H}_{12} \mathrm{O}_{2}: \mathrm{C}$, 73.15; H, 7.37. Found: $\mathrm{C}, 72.99 ; \mathrm{H}, 7.57$. ${ }^{1} \mathrm{H} \operatorname{NMR}\left(\mathrm{CCl}_{4}, \delta\right): 1.26(3 \mathrm{H}, \mathrm{d}, J=6.0 \mathrm{~Hz}$,
$\left.\mathrm{CH}_{3}\right), 3.2 \sim 4.3\left(3 \mathrm{H}, \mathrm{m}, \mathrm{MeCH}(\mathrm{O}) \mathrm{CH}_{2} \mathrm{O}\right)$, 5.61 (s, $\mathrm{HC}<<_{\mathrm{O}}^{\mathrm{O}}$ cis), 5.77 (s, $\mathrm{HC}<\mathrm{O}_{\mathrm{O}}^{\mathrm{O}}$ trans), 7.1 7.4 $\left(5 \mathrm{H}, \mathrm{m}, \mathrm{C}_{6} \mathrm{H}_{5}\right)$. Mass spectrum (20 $\mathrm{eV}): m / e 163$ (ra 100), 106 (93), $164\left(\mathrm{M}^{+}\right.$, 83), 79 (52), 88 (40), 92 (34), 60 (28), and 91 (25).

To a stirred solution of $\mathrm{LiBr}(1.6 \mathrm{~g}, 15 \mathrm{mmol})$ in HMPA $(26.9 \mathrm{~g}, 150 \mathrm{mmol}$ ) was added 15.9 g ( $150 \mathrm{mmol})$ of benzaldehyde, followed by dropwise addition of $10.8 \mathrm{~g}(150 \mathrm{mmol})$ of $\mathrm{BO}$. After being stirred at reflux $\left(95 \sim 117^{\circ} \mathrm{C}\right)$ for $7 \mathrm{~h}, 10.8 \mathrm{~g}(150 \mathrm{mmol})$ of $\mathrm{BO}$ was added to the mixture. The mixture was heated at reflux for an additional $8 \mathrm{~h}$. The resulting solution was treated by the procedure described above and $3.2 \mathrm{~g} \mathrm{(20 \% )}$ of benzaldehyde was recovered. The product (4) was obtained by distillation (17.3 g, 65\%). bp $143 \sim 145^{\circ} \mathrm{C} / 3 \mathrm{mmHg}$. IR (neat): 1230, 1115, 1090, 1070, 1030, 980, 960, 920, 760, and $700 \mathrm{~cm}^{-1}$. Anal. Calcd. for $\mathrm{C}_{11}=$ $\mathrm{H}_{14} \mathrm{O}_{2}: \mathrm{C}, 74.13 ; \mathrm{H}, 7.92$. Found: C, 73.97; $\mathrm{H}, 8.07 .{ }^{1} \mathrm{H} \mathrm{NMR}\left(\mathrm{CCl}_{4}, \delta\right): 0.93(3 \mathrm{H}, \mathrm{t}, J=$ $\left.6.0 \mathrm{~Hz}, \mathrm{CH}_{3}\right), 1.3 \sim 1.8\left(2 \mathrm{H}, \mathrm{m}, \mathrm{CH}_{2}\right), 3.2 \sim$ $4.1\left(3 \mathrm{H}, \mathrm{m}, \mathrm{EtCH}(\mathrm{O}) \mathrm{CH}_{2} \mathrm{O}\right), 5.60(\mathrm{~s}, \mathrm{HC}<\mathrm{O}$, cis), $5.76\left(\mathrm{~s}, \mathrm{HC}<{ }_{\mathrm{O}}^{\mathrm{O}}\right.$, trans $), 7.0 \sim 7.4(5 \mathrm{H}$, $\mathrm{m}, \mathrm{C}_{6} \mathrm{H}_{5}$ ). Mass spectrum $(30 \mathrm{ev}): 177$ (ra 100), 106 (45), 56 (45), $178\left(\mathrm{M}^{+}, 43\right), 92(41)$, 79 (26), 123 (19), and 78 (19).

\section{Results and Discussion}

Reaction of 1-chloro-2,3-epoxypropane (ECH) with benzaldehyde

The reaction of $\mathrm{ECH}$ with benzaldehyde at $120^{\circ} \mathrm{C}$ in the presence of $\mathrm{LiBr}$ in HMPA gave 4-(chloromethyl)-2-phenyl-1, 3-dioxolane (1). The product was a mixture of stereoisomers in which the substituent group at $2-\mathrm{C}$ and $4-\mathrm{C}$ were in cis (1 a)- and trans (1 b)- configura= tion. The structures of cis- and trans-isomers were estimated on the basis of chemical shifts of the H-2 protons in NMR spectra. The closer proximity of the 4 -(chloromethyl) group and $\mathrm{H}-2$ proton in the trans-2,4-disubstituted dioxo= lane should lead to mutual deshielding and therefore, to a shift of the $\mathrm{H}-2$ signal to lower field than for the cis-isomer, similar to that reported for the diastereoisomeric 4-(acetoxy= methyl)-2-pentadecyl dioxolanes ${ }^{9,10)}$ and 4- 
(halomethyl)-2-methyl dioxolanes ${ }^{11}$. Actually, the chemical shift for $\mathrm{H}-2$ in (1 a) was found to be $5.82 \mathrm{ppm}$ and the corresponding signal of (1 b) was shifted to lower field (6.02 ppm).

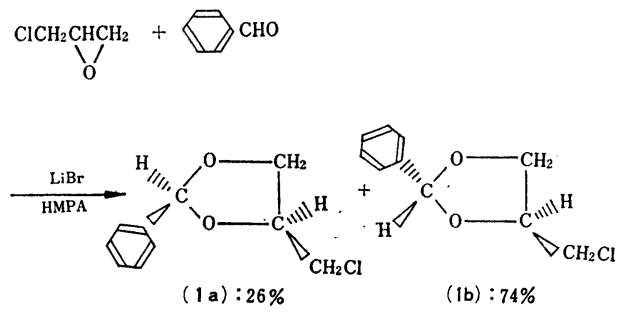

In order to optimize the synthetic conditions and to get information regarding the reaction mechanism, we examined the effect of solvent and catalyst on the yield of 1,3-dioxolane. In the reaction in nonpolar solvent, such as benzene and carbon tetrachloride, whole amount of benz= aldehyde was recovered. However, the addi= tion of a small amount of HMPA to benzene resulted in the formation of (1), as shown in Table-1. In the reaction in $N, N$-dimethyl=

\begin{tabular}{|c|c|c|c|c|}
\hline \multirow{2}{*}{ Solvent } & \multicolumn{2}{|c|}{ Reaction conditions } & \multirow{2}{*}{$\begin{array}{l}\text { Recovery of } \\
\text { benzaldehyde } \\
\text { (\%) }\end{array}$} & \multirow{2}{*}{$\begin{array}{r}\text { Yield } \\
\text { of (1) } \\
(\%)\end{array}$} \\
\hline & $\begin{array}{l}\text { Temp. } \\
\left({ }^{\circ} \mathrm{C}\right)\end{array}$ & $\begin{array}{l}\text { Time } \\
\text { (h) }\end{array}$ & & \\
\hline HMP A & 120 & 5 & 27 & 52 \\
\hline $\mathrm{DMF}$ & 120 & 5 & 69 & 17 \\
\hline DMA & 120 & 5 & 55 & 27 \\
\hline NMP & 120 & 5 & 50 & 24 \\
\hline Benzene* & 85 & 5 & 65 & 13 \\
\hline $\mathrm{THF}^{*}$ & 85 & 5 & 67 & 14 \\
\hline
\end{tabular}

* A combination of $\mathrm{LiBr} / \mathrm{HMPA}(1: 1)$ was used as a catalyst.

formamide (DMF), $N, N$-dimethylacetamide (DMA) and $N$-methylpyrrolidone (NMP), dioxolane (1) was obtained in a lower yield (Table-1). HMPA was the most suitable sol= vent and may act not only as a solvent but also specifically solvate the lithium ion to enhance the nucleophilicity of the resulting "naked" halide ion ${ }^{12)}$. Among lithium halides, $\mathrm{LiCl}$ and $\mathrm{LiBr}$ were suitable catalysts. The yield of $\mathrm{di}=$ oxolane, however, was low when lithium iodide was employed as a catalyst, which may be due to its low solubility. The situation was the same for tetraethylammonium bromide (TEAB) and the yield was low due to its low solubility
(Table-2). The yield of (1) increased with increasing temperature up to $120^{\circ} \mathrm{C}$. Above 140 ${ }^{\circ} \mathrm{C}$, however, the reaction led to the formation of dark resinous matter.

Table-2 Reactions of ECH with benzaldehyde in HMPA in the presence of various salts.

\begin{tabular}{l|c|c|c}
\hline Catalyst & $\begin{array}{c}\text { Reaction } \\
\text { temp. } \\
\left({ }^{\circ} \mathrm{C}\right)\end{array}$ & $\begin{array}{c}\text { Recovery of } \\
\text { benzaldehyde } \\
(\%)\end{array}$ & $\begin{array}{c}\text { Yield of } \\
(\mathbf{1}) \\
(\%)\end{array}$ \\
\hline $\mathrm{LiCl}$ & 120 & 39 & 53 \\
$\mathrm{LiBr}$ & 120 & 27 & 52 \\
$\mathrm{LiBr}$ & 90 & 50 & 33 \\
$\mathrm{LiI}$ & 120 & 74 & 9 \\
$\mathrm{TEAB}$ & 120 & 72 & 16 \\
\hline
\end{tabular}

Reaction time: $5 \mathrm{~h}$.

\section{Reaction of ECH with cyclohexanone}

The reaction of $\mathrm{ECH}$ with cyclohexanone in $\mathrm{HMPA}$ in the presence of $\mathrm{LiBr}$ at $140^{\circ} \mathrm{C}$ gave 1,4-dioxa-2-(chloromethyl)spiro[4,5]decane (2) in the yield of $17 \%$. In the presence of $\mathrm{LiCl}$ and TEAB, the yield of (2) was $12 \%$ and $3 \%$, respectively.

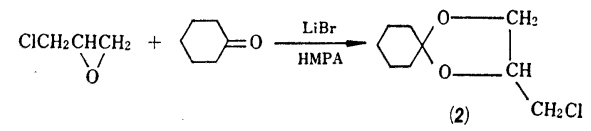

Reaction of 1,2-epoxypropane (PO) and 1,2-epoxybutane (BO) with benzaldehyde

The reaction of $\mathrm{PO}$ and $\mathrm{BO}$ with benzal= dehyde in HMPA in the presence of $\mathrm{LiBr}$ gave $53 \%$ yield of 4-methyl-2-phenyl-1,3-dioxolane (3) and $65 \%$ yield of 4-ethyl-2-phenyl-1,3dioxolane (4), respectively. Dioxolanes (3) and (4) were obtained as mixtures of stereoisomers in which 2-phenyl and 4-alkyl groups were in the cis- and trans-configuration. None of the stereoisomers was isolated, but the presence of the cis- and trans-isomers was confirmed by occurrence of two kinds of $\mathrm{H}-2$ signals in ${ }^{1} \mathrm{H}$ NMR spectrum. [5.61 and $5.77 \mathrm{ppm}$ in (3), and 5.60 and $5.76 \mathrm{ppm}$ in (4).]

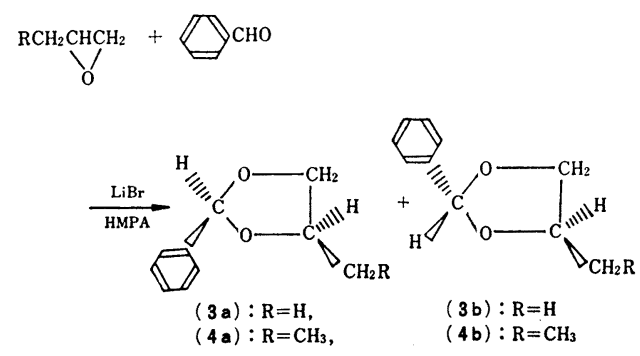


Effect of catalyst on the isomer ratio of 2, 4-disubstituted 1,3-dioxolanes

The reaction of unsymmetrically substituted epoxides with benzaldehyde gave the mixtures of isomeric 1,3-dioxolanes in which the cons figuration of 2 - and 4-substituents was cis and trans. The cis/trans ratio determined by the measurement of signal areas of $\mathrm{H}-2$ in ${ }^{1} \mathrm{H}$ NMR spectra was dependent on the type of catalyst. The result is summarized in Table-3. In the Lewis acid catalyzed reactions, the cis-isomer was preferentially formed, conversely the lithium halide catalyst offered the trans-isomer pref $=$ erentially.

Table-3 Effect of catalyst on the cis/trans ratio of 1,3-dioxolanes from epoxide and benzaldehyde.

\begin{tabular}{|c|c|c|c|c|c|}
\hline Epoxide & Catalyst & $\begin{array}{l}\text { Reaction } \\
\text { temp. } \\
\left({ }^{\circ} \mathrm{C}\right)\end{array}$ & $\begin{array}{c}\text { Reaction } \\
\text { time } \\
\text { (h) }\end{array}$ & $\begin{array}{c}\text { cis } \\
(\%)\end{array}$ & $\begin{array}{l}\text { trans } \\
(\%)\end{array}$ \\
\hline $\mathrm{ECH}$ & $\mathrm{LiBr}$ & 120 & 15 & 26 & 74 \\
\hline $\mathrm{ECH}$ & $\mathrm{LiCl}$ & 120 & 5 & 30 & 70 \\
\hline $\mathrm{ECH}$ & $\mathrm{AlCl}_{3}{ }^{\mathrm{a})}$ & 66 & 5 & 67 & 33 \\
\hline $\mathrm{PO}$ & $\mathrm{LiBr}^{b)}$ & 120 & 8 & 23 & 77 \\
\hline $\mathrm{BO}$ & $\mathrm{LiBr}$ & Reflux & 15 & 25 & 75 \\
\hline $\mathrm{BO}$ & $\mathrm{AlCl}_{3}^{a)}$ & 75 & 4 & 63 & 37 \\
\hline $\mathrm{ECH}$ & $\mathrm{BF}_{8} \mathrm{OEt}_{2}{ }^{\mathrm{c})}$ & 40 & 5 & 58 & 42 \\
\hline
\end{tabular}

a) The $\mathrm{AlCl}_{3}$ catalyzed reactions were carried out in the absence of solvent.

b) The reaction of $\mathrm{PO}$ was carried out in a sealed tube.

c) The $\mathrm{BF}_{8}$ catalyzed reaction was carried out in $\mathrm{CCl}_{4}$.

The difference in the isomer ratio between Lewis acid and lithium halide catalysts may be explain by the following reaction scheme. In the Lewis acid catalyzed reaction, the initiation of the reaction might be the attack of aldehyde oxygen to the ring carbon of Lewis acid coor= dinated epoxide (oxonium ion), in a similar manner to that suggested by Blackett ${ }^{6}$ ). The attack of aldehyde on the unsubstituted carbon of epoxide ring is advantageous owing to steric effect. From the observation of cpk model, the rotations of $\mathrm{C}-\mathrm{C}$ bond and $\mathrm{C}-\mathrm{O}$ bond in the shift of transition state (b) to (c) may be re= stricted to the direction illustrated in Scheme-1 because of the steric effect of $\mathrm{R}^{\prime}, \mathrm{H}^{\prime}$ and $\mathrm{H}^{\prime \prime}$. Thus Lewis acid catalyst offered the cis-isomer preferentially.

Conversely, the lithium halide catalyzed reacs

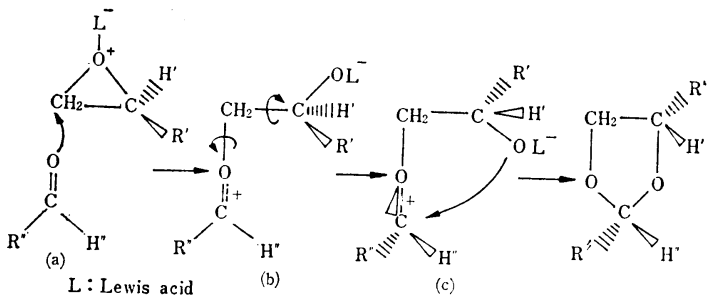

Scheme-1

tion may proceed by the attack of halohydrin alkoxide ion, which is formed by the nucleo= philic attack of halide ion on the ring carbon of epoxide, on the aldehyde carbon and lead to the preferential formation of the trans isomer because of steric effect. (Scheme-2)

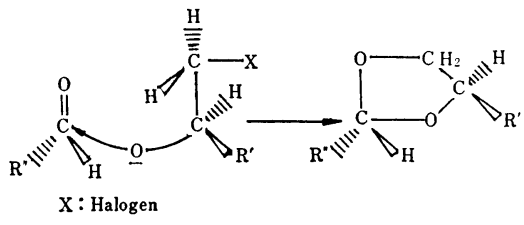

Scheme-2

The authors would like to thank Professor Mitsuo Okahara and Assistant Professor Isao Ikeda of Osaka University for helpful discussion.

(Received March 5, 1981)

\section{References}

1) I. Maruyama, M. Nakaniwa, T. Saegusa, and J. Furukawa, Kogyo Kagaku Zasshi, 68, 1149 (1965).

2) R.F. Fischer and C.W. Smith, J. Org. Chem., 25, 319 (1960).

3) J.F.W. McOmie, Chem. Ind. London, 1979, 603.

4) B. Burczyk and L. Weclas, Tenside Deterg., 17, 21 (1980).

5) (a) E.J. Witzemann, W.L. Evans, H. Hass, and E.F. Schroeder, "Organic Syntheses", Coll. Vol. II, p. 137 (1943). (b) S.M. McElvain and D. Kundiger, ibid., Coll. Vol. III, p. 123 (1955). (c) M. Renoll and M.S. Newman, ibid., Coll. Vol. III, p. 502 (1955).

6) (a) M.T. Rogert and R.D. Roblin Jr., J. Am. Chem. Soc., 55, 3741 (1933). (b) T. Bersin and G. Willfang, Chem. Ber., 70B, 2167 (1937). (c) G. Willfang, ibid., 74B, 145 (1941). (d) J.L.E. Erickson and F.E. Collins Jr., J. Org. Chem., 30, 1050 (1965). (e) A.A. Petrov, Zhur. odsheh. khim. J. Gen. Chem. (USSR), 
10, 981 (1940). I(f) F. G. Ponomarev, Doklady Akad. Nauk S.S.S.R., 108, 648, (1956) Chem. Abstr., 51, 3565 (1957). (g) B.N. Blackett, J.M. Coxon, M.P. Hartshorn, A.J. Lewis, G.R. Little, and G.E. Wright, Tetrahedron, 26, 1311 (1970).

7) T. Takeda, S. Yasuhara, and S. Watanabe, Nippon Kagaku Kaishi, 1981, 466

8) F. Nerdel, J. Buddrus, G. Scherowsky, D. Klamann, and M. Fligge, Libigs Ann. Chem., 710, 85 (1967).

9) W.J. Baumann, J. Org. Chem., 36, 2743 (1971).

10) Y. Wedmid, C.A. Evans, and W.J. Baumann, J. Org. Chem., 45, 1582 (1980).

11) F. Borremans, M. Anteunis, and F.A.-D. Kete= laere, Org. Mag. Res., 5, 299 (1973).

12) T. Takeda, S. Yasuhara, and S. Watanabe, Bull. Chem. Soc. Jpn., 53, 2566 (1980).
エポキシドとカルボニル化合物からの中性 条件下での 1,3-ジオキソランの合成

武田徳司・安原 諭・渡辺昭二

大阪市立工業研究所 (大阪市北区扇町 2-1-1)

エポキシドとカルボニル化合物を極性非プロトン溶媒 中，八ロゲン化リチウム触媒で反応させることにより 1,3-ジオキソラン誘導体が得られた。非対称エポキシド (1-クロロ-2,3-エポキシプロパン，1,2-エポキシプロパ ン及び 1,2-エポキシブタン) とベンズアルデヒドから 得られた 2,4-ジ置換-1,3-ジオキソランは，2-と 4-置 換基がシスとトランスの配置をした立体異性体の混合物 であることがわかった。得られた 1,3-ジオキソランの シス/トランス比は触媒のタイプに依存した。すなわち, ルイス酸接触反応ではシス異性体が優先して生成し, 逆にハロゲン化リチウム触媒はトランス異性体を優先し て生成した。 